\title{
PIRACY OF AIRCRAFT AND THE LAW
}

\author{
L. C. GREEN*
}

\begin{abstract}
Aerial hijacking or aerial piracy presents a serious threat to the personal safety of air travellers as well as to orderly international air transport. As the problem is relatively new the rights of the state or states involved against the hijacker, as well as the hijacker's personal rights within the new state, are confused due to attempts to make old international and municipal concepts fit a contemporary hybrid problem. In order to discover a basis for state jurisdiction and hijacker liability, Professor Green analyses the extraditable offence of piracy as well as international conventions and jurisprudence. The author concludes that customary inter. national law rules regarding extradition are inadequate to deal with the problem of aerial piracy. Therefore, in view of its widespread international effect, the only effective method of dealing with the problem is by way of multilateral treaty regulation such as the 1970 Hague Convention for the Suppression of Unlawful Seizure of Aircraft.
\end{abstract}

The recent diversion of an American aircraft from its scheduled flight pattern to a Canadian airport at the instruction of a passenger on board has shown that the motivations of this type of action may be extremely personal, although in the past, and particularly since Arab guerrillas took a hand in the game, such diversions usually had fairly obvious political overtones. But in every case the problem that presents itself to the country in which the aircraft has been compelled to land is whether the person responsible for the deviation is to be allowed to stay, whether he is to be deported or whether he is liable to extradition.

In so far as extradition is concerned, the problem up to the present has been fairly simple. There is no rule of customary international law requiring a country of refuge to extradite any alleged offender at the mere request of the state alleging that its criminal law has been breached. International practice, while not forbidding the state of refuge from handing over such a fugitive, has developed so that a duty to extradite only arises when there is a treaty to this effect between the two countries concerned. Moreover, the treaty must specifically provide for extradition in respect of the particular crime alleged. It is not enough to provide for extradition in respect of all offences covered by the penal code of either country. Practice dictates that extradition crimes be listed. In addition, most countries go further and decline to extradite merely on the basis of the treaty. Instead, they enact municipal legislation providing for the procedure to be followed in the event of extradition being requested, and the statute normally lists the crimes for which it will be granted. This means that extradition will only be possible if the alleged offence is listed by both the treaty and the relevant statute of the state from which extradition is being requested. ${ }^{1}$ In addition, most countries insist that the offence for which extradition is sought should be one that is criminal by the law of both the requesting and the requested country,

\footnotetext{
- University Professor, University of Alberta.

' As to the position in Canada, see La Forest, Extradition to and From Canada (1961)-the relevant legislation appears as App. 1.
} 
although complete identity of nomenclature and the like is not essential. ${ }^{2}$ However, even in the absence of an extradition treaty, there is no obligation upon the state of refuge to receive the fugitive and it may, by way of declaring him an undesirable or forbidden immigrant, refuse to admit him or insist upon his deportation, even to the country from which he has fled and which would, because of the absence of a treaty or because the offence is not extraditable, be unable to secure his return in the normal way. ${ }^{3}$

Applying the rules set out above, there is little chance of those who commit what is sometimes described as piracy in the air or aerial hijacking being extradited, for this is a comparatively new offence unlikely to appear in any of the treaties or statutes concerned with extradition. It is true that most of these regard piracy as an extraditable offence, provided this is piracy jure gentium, ${ }^{4}$ for a state may well by its criminal law provide for a special definition of piracy, but this is only valid for its own nationals and cannot be extended against aliens operating on the high seas. ${ }^{5}$ But what is piracy jure gentium? According to the Judicial Committee of the Privy Council, the pirate is hostis humani generis and justiciable by any state anywhere, and his crime must involve an act of violence on the high seas. ${ }^{6}$ However:

...careful examination of the subject shows a gradual widening of the earlier definitions of piracy to bring it from time to time more in consonance with situations either not thought of or not in existence when the older jurisconsults were expressing their opinions.

Aerial warfare in the Second World War indicated that aircraft could be used in attacks against shipping, ${ }^{8}$ and when the Geneva Conference on the Law of the Sea came to consider the adequacy of traditional views concerning piracy it was fully cognizant of this fact. Article 15 of the Convention on the High Seas $^{9}$ defines piracy as:

... any illegal acts of violence, detention or any act of depradation, committed for private ends by the crew or the passengers of a private ship or a private aircraft, and directed (a) on the high seas, against another ship or aircraft, or against persons or property on board such ship or aircraft; (b) against a ship, aircraft, persons or property in a place outside the jurisdiction of any State... .

It is clear that the first of these paragraphs excludes seizures of the vessel by persons thereon, for it specifies that action must be taken against "another" craft. The second paragraph is more ambiguous, but failure to use the word "any" instead of " $a$ " suggests that even this offence is directed against an object outside the craft on which the alleged pirate is travelling-in fact, O'Connell suggests that mutiny, though regarded as piracy in U.S. v. Klintock, ${ }^{10}$ may now be outside

\footnotetext{
2 In re Arton (No. 2) [1896] 1 Q.B. 509. Cp. Eisler Case. The Times (London), May 28, 1949; Green, Recent Trends in the Law of Extradition, (1953) 6 Current Legal Problems 274 at 284-287; Finch. The Eisler Extradition Case, (1949) 43 Am. J. Int. L. 487.

${ }^{3}$ See R. v. Governor of Brixton Prison, ex p. Soblen [1963] 2 Q.B. 243; O'Higgins, Disquised Extradition: The Soblen Case, (1964) 27 Mod. L. Rev. 521.

- For Canadian treaties, see list in La Forest, supra, n. 1 at 180; for the relevant statutory provisions, see Extradition Act, R.S.C. 1970, c. E.21, Schedule I, s. 20.

"The Le Luis (1817) 2 Dods. 210, 165 E.R. 1464.

6 In re Piracy Jure Gentium [1934] A.C. 586 at 589.

IId. at 600 .

B See for account of surrender of a U.boat to an aircraft of Coastal Command, Spaight, Air Power and War Rights 132-133 (1947).

950 UNTS 11.

I0 (1820) 5 Wheat. 144 at 152.
} 
the scope of the definition.11 A further consideration which suggests that the seizure of an aircraft by a person on board that aircraft does not amount to piracy appears from Article 21 of the Convention, which requires the seizure of a pirate to be effected by "warships or military aircraft, or other ships or aircraft on government service authorized to that effect." This would obviously prevent a person on the ground at the airport to which the seized aircraft had been diverted from arresting the captor on the ground of piracy, whatever be the status of the person effecting the arrest. In any case, the International Law Commission, which was responsible for drafting the Convention, stated in its Commentary on Article 15, which as drafted did not mention aircraft, but which applies equally to them as well: "Acts comimitted on board a ship by the crew or passengers and directed against the ship itself, or against persons or property on the ship, cannot be regarded as acts of piracy."12 It would appear, therefore, that while aircraft can be pirate vessels and used to commit piracy, in order that the hijacking of an aircraft should be considered as falling within this crime, there will have to be a multilateral treaty to this effect if there is to be any impact on international law, although municipal law may of course be amended to extend the definition to cover the acts of those within the jurisdiction. Moreover, the present international definition makes it clear that piracy can only be committed upon the high seas or in a place which is outside the jurisdiction of any state. An act of apparent piracy, therefore, within the air space of any state would not satisfy the international definition.

While piracy itself may not be involved when an aircraft is hijacked, there may well be a series of other offences that fall for consideration. In the first place, of course, there may according to certain systems of municipal law be questions of liability arising from interference with scheduled air traffic, or, if the flight involved has deviated from regular routing, from its endangering other aircraft. In addition, and this applies equally to the diverted machine as well as to other aircraft in the line of flight, the lives and safety of crew and passengers may well have been endangered. Furthermore, criminal liability may arise in connection with the sanctity of property, both in so far as luggage is concerned and as regards unlawful detention of the aircraft itself. In some cases, as happened with aircraft hijacked by Arab guerrillas, there may even be ground for charging the persons involved with the destruction of property. In addition, there might be problems concerning unlawful imprisonment or temporary abduction of passengers and crew, as well as civil actions at the suit of passengers or crew members. Finally, interesting questions with regard to the law of immigration may be involved as well.

In a recent Canadian case these aspects of the matter were very much to the fore. ${ }^{13}$ The young hijacker, Paterson aged 19, stated that he wished to be categorised as a landed immigrant in Canada and therefore sought by way of habeas corpus to ascertain the reason for his detention by Department of Immigration officials, for, although

\footnotetext{
1 International Law 659, n. 82 (2d. vol. 1970).

12 (1956) 2 U.N. Yearbook of the International Law Commission 282.

13 The Toronto Globe and Mail, March 2, 3, 9, 1971.
} 
he had been charged with aerial piracy in the United States under the municipal legislation of that country, no formal request for his extradition had been made and, so far as was publicly known, no other United States request made for his return. On behalf of the Department it was stated that it was contrary to Immigration Regulations for Paterson to receive landed status, since he had failed to obtain a letter of pre-examination from a Canadian official abroad, which is a prerequisite for residence. Such letters may be obtained within Canada only if the applicant entered the country legally. The Department also contended that the applicant was not a bona fide immigrant in that he had been charged in his own country with an offence involving moral turpitude, namely aerial piracy, and since there was a valid warrant out for his arrest in the United States he was a fugitive from justice. Before the court could decide the issue, the Department of Immigration proceeded to issue a deportation order, and the application before the court was changed to include the claim that, as a result of bad weather counsel for the applicant had not been present when the Department made its decision and therefore there had been a denial of justice under the Canadian Bill of Rights. For the Crown it was pointed out, fully in accordance with international law, that every state is entitled to deny immigration to whomever it wished and that it would be for the applicant to prove a right to remain. It was also pointed out that the Regulations provide for an appeal board, the decisions of which are not subject to review by the courts, and that an appeal against a deportation order on behalf of a United States citizen can only be made by the applicant after his return to the United States. Dryer J. of the British Columbia Supreme Court denied the application on the ground that there had been no breach of the Bill of Rights, and no failure to comply with justice. Immediately the decision was handed down, immigration officials escorted Paterson to the border where he was handed over to United States authorities. Even if the United States officials had come into Canada to accept the body of the fugitive, there would have been no breach of law if they did so with the consent of the Canadian authorities. Unlike cases involving, for example, draft evadees in Canada legally, this individual was not entitled to any of the protection of Canadian law since, having never been allowed in, he had not technically come within the Queen's protection and, in the light of Soblen, ${ }^{14}$ it might even be argued that he was not in the country. Having decided within the discretion allowed them by law that Paterson was subject to a deportation order, the Department of Immigration was fully entitled to escort the fugitive to the border to ensure his departure. It was merely fortuitous that the nearest border was that of the country from which he was actually a fugitive. In order to prevent a further illegal entry, the Canadian officials can not be faulted for having handed him into the custody of the neighbouring authorities who would have undertaken to ensure that he did not again enter Canada illegally.

As a matter of general practice states do not normally extradite or return fugitives accused of military offences so that they may stand trial. This ruling would not of course interfere with the receiving

\footnotetext{
"supra, n. 3.
} 
state's right to deport the individual as an illegal immigrant or an undesirable alien. But was Peterson in fact a military fugitive in the sense of the law of extradition? Unlike deserters who are subject to military law, or draft evaders whose offence is not listed in the treaty, Paterson, who had hijacked the aircraft while on his way to an induction ceremony, was not charged with any military offence, but with one in respect of which a warrant had been issued alleging aerial piracy, a federal offence amenable to the death penalty. ${ }^{15}$

The attitude of the Canadian authorities in this case is far more understandable and defensible than that of the Turkish courts in connection with the hijacking of a Soviet aircraft in October 1970 by a Lithuanian and his son. The Soviet authorities were contemporaneously holding a United States military officer, based in Turkey, who had inadvertently crossed the Soviet border, and it soon became clear that a political quid pro quo might be involved. The Soviet Union requested the extradition of the two hijackers, even though no extradition treaty existed between her and Turkey. The Turkish court held that the offence was political in character and that the fugitives were entitled to political asylum. At about that time the Soviets released the American officer without having brought any charges against him, and an appeal against the decision was lodged on behalf of the Turkish government. In March 1971 the Supreme Court of Appeal in Ankara reversed the earlier decision and held that the offence was an ordinary crime and amenable to extradition, leaving the final decision to the Turkish government. ${ }^{16}$ The political implications of the case appear obvious, especially since there was no treaty. However, one cannot ignore that in the exercise of its discretion the Canadian Department of Immigration may also be politically motivated, but at least there are guidelines, and the Paterson case was decided without any regard to extradition processes.

The Turkish decision raises the question whether aerial hijackers are able to plead that their offences are political in character and therefore that it matters little by what strategem their actions are brought within the scope of extradition treaties, as they are exempt from extradition and entitled to be treated as political offenders. Such cases as the Arab hijackings, culminating in the destruction of the aircraft involved, or escapes from countries with whose governmental processes the fugitive disagrees may prima facie appear to be politically motivated. The same may, in the eyes of some, be said of those who refuse to serve in the armed forces, especially when they contend that the war in which their country is involved is illegal, or immoral, or contrary to their beliefs. However, it must be borne in mind that the easiest contention that may be put forward in this type of case, and perhaps one of the most difficult to disprove, is that the fugitive was motivated by and acting in accordance with conscientious or political motives. Thus, in March 1971 a sixteen-year-old American youth attempted to divert a National Airlines aircraft to Canada. Apparently he was having difficulties at home and at school, but

\footnotetext{
is Federal Aviation Act, 1958, s. 902 (as amended); 75 Stat. 466 (1961), 49 U.S.C.A., 8. 1472. See also 1970 Stats. at Large, Pub. Laws. 91 st. C. 449, 8. 2176.

16 The Times (London), March 8, 1971.
} 
wished to go to Canada because "there were a lot of draft dodgers there."17

In order to determine whether an aerial hijacker is entitled to plead that his offence was political and that he is therefore entitled to enjoy political asylum, it becomes necessary to examine what international law has to say about both asylum and the political offender. By Article 14 of the Universal Declaration of Human Rights, 1948:18

...everyone has the right to seek and enjoy in other countries asylum from persecution [,but] this right may not be invoked in the case of prosecution genuinely arising from non-political crimes or from acts contrary to the purposes and principles of the United Nations.

and among these purposes and principles is the promotion of friendly relations among states and of the rule of law. But although the Declaration postulates this "right", it does not impose any concomitant duty upon any state to grant the asylum which is being sought. The "right" is therefore somewhat unreal and perhaps only of moral and ideological value. Moreover, the Declaration is only a Resolution of the General Assembly of the United Nations, which has not been embodied in an agreement to which any state has appended its signature, and which lacks binding force as do almost all the resolutions of the Assembly except those which may be described as of an internal housekeeping character in so far as the Organisation itself is concerned. These criticisms apply equally to the 1967 Resolution which is sometimes described as the Declaration on Asylum. ${ }^{19}$ This too imposes no obligation to grant asylum-in fact "it shall rest with the state granting asylum to evaluate the grounds for the grant of asylum ... [which is] granted by a state in the exercise of its sovereignty." That the members of the United Nations, that is to say almost all the states in the world, are not prepared to concede any duty in this respect becomes even clearer if one examines the document that was alleged to give legal force to the protection of human rights. The International Covenant on Civil and Political Rights, ${ }^{20}$ which was opened for signature at the end of 1966 and still lacks sufficient ratifications to become effective, makes no reference whatever to any right of asylum. It is true that regional groups have sometimes entered into treaty obligations guaranteeing a right of asylum, as do certain state constitutions, but these are not relevant if one is considering the problem from the point of view of universal international law. The nearest one comes to a general treaty embodying a right of asylum is the 1951 Convention on the Status of Refugees. ${ }^{21}$ By Article 1, asylum is to be granted to those unable or unwilling to return to their original countries because of "well-founded fear of being persecuted for reasons of race, religion, nationality, membership of a particular social group or political opinions," but the definition of "refugees" to whom this right is to be extended is so narrow that it cannot possibly include within its purview those whose acts against aircraft are now being described as piratical.

\footnotetext{
17 The Toronto Globe and Mail, March 9, 1971.

18 Res. 217 (III).

10 Res. 2312 (XXII), Art. 1.

20 Res. 2200 (XXI).

21 189 UNTS 137.
} 
In view of the absence of any multilateral treaty or definition of asylum, it becomes necessary to look at the position under municipal law by examining the attitude courts have taken to the plea of political offence, bearing in mind that by Article 38 of the Statute of the World Court one of the "sources" of international law is the general principles of law recognized by civilized nations. If one can determine the nature of political offences by this examination, then it becomes possible to examine whether an aerial hijacker would have any ground for pleading that his offence was political in character in order to save him from extradition in respect of any of the concomitant charges that might be brought against him. It must be borne in mind, however, that frequently cases of hijacking never come before the courts, for the country of refuge finds the alleged basis for the hijacking itself to be one with which it is in political sympathy. As a result it is prepared to declare that the persons responsible for the hijacking are simple political dissenters who have found that this is the only way in which they can give expression to their dissent, or that the conditions in the country against which the demonstration has been made are such that the government of that country has only itself to blame. Thus, at the end of January 1971, two Kashmiris hijacked an Indian Airlines aircraft and diverted it to Lahore in Pakistan, demanding as the price of the safety of the plane the release of "all political prisoners rotting in Indian jails" because of the Kashmir dispute. The status of Kashmir has been in dispute between India and Pakistan for years, and during the 1971 general election in India restrictive measures were taken against certain political parties in the territory. Immediately upon the arrival of the aircraft in Lahore, the Government of Pakistan extended political asylum to the two aerial "pirates". When rejecting the Kashmiris' demands, the Indian Government condemned the act as a "crime against humanity", described the hijackers as "criminals", and expressed "surprise that the Pakistan Government should have found it fit to grant them asylum,"22 especially as the recent arrests in Kashmir were a matter of internal concern and no government had the right to interfere. This last statement suggests that the Government of India is unaware of the whole concept of political offences, for the basis of the exception of political offenders from the extradition process is precisely the conditions in the country from which the flight has taken place. However, there may be some small justification for this in view of the fact that, apparently, the Indian courts have never really been called upon to consider the nature of political offences in connection with extradition. ${ }^{23}$

While the Indian courts may not have had the opportunity to consider the nature of the political offence, the courts in a variety of other countries have, and a definition has evolved that seems generally accepted and which is based to a very great extent on English practice. $^{24}$ In $R \dot{e}$ Castioni Denman J. declared that for an act to be

\footnotetext{
22 The Times (London), February 1,2,1971.

23 Hingorani, The Indian Extradition Law 51 (1969).

24 See Green, The Nature of Political Offences, (1964) 3 The Solicitor Quarterly 213, Hijacking and the Right Of Asylum, in McWhinney, Aerial Piracy and International Law (1971, in the preso), Papadatos, Le delit Politique (1954).
} 
considered political in connection with a request for exemption from extradition: ${ }^{25}$

...it must at least be shewn that the act is done in furtherance of, done with the intention of assistance, as a sort of overt act in the course of acting in a political manner, a political rising, or a dispute petween two parties in the State as to which is to have the government in its hands.... The question really is, whether, upon the facts, it is clear that the man was acting as one of a number of persons engaged in acts of violence of a political character with a political object, and as part of the political movement and rising in which he was taking part.

Such a definition would not extend to a private act taken by a single individual for private motives, or taken for his own political ends, or because he was politically opposed to the country in which the offence was alleged to have been committed. As a result of this emphasis on the need for organisation, it has been held that one who committed an offence and who maintained that he was an anarchist and had committed his offence in furtherance of the 'political aims' of the 'movement', could not enjoy the rights of protection extended to a political offender, for: ${ }^{26}$

... to constitute an offence of a political character, there must be two or more parties in the State, each seeking to impose the Government of their own choice on the other, and that, if the offence is committed by one side or the other in pursuance of that object, it is a political offence, otherwise not.

This ban on the extension of political asylum to anarchists has been applied in Europe, and some of the Latin Americans have embodied it into their constitutions, while there exist a Pan-American Convention for the Extradition of Criminals and for Protection Against Anarchism, 1902,27 and a Central American Extradition Convention, $1934,{ }^{28}$ which make it obligatory by treaty not to recognise anarchic acts as political offences. In view of the fact that many of the young people who have been involved in acts of aerial piracy describe themselves as supporters of anarchism, this refusal to concede that anarchical acts constitute political offences makes it difficult, so long as the present trends in judicial practice continue, for any of them to evade extradition for offences arising from or connected with hijacking.

Even persons who are members of recognised political parties may find themselves denied political refuge in face of a request for extradition on the ground that their act was not really identified with a political purpose aimed at securing the overthrow of the existing government and its replacement by one committed to the beliefs of the party to which the offender belonged. This was the position in Re Federenko (No. 1), ${ }^{29}$ the only Canadian case in which the nature of political offences has had to be considered. The accused, a member of the Social Democrats, was charged with killing a watchman in a village which was under martial law. The fact of his political affiliation was not known to the arresting party which had been investigating the presence of strangers and had called upon them to account

\footnotetext{
25 [1891] 1 Q.B. 149 at 156,159 .

26 In re Meunier [1894] 2 Q.B. 415 at 419 (per Cave J.).

276 Martens, Nouveau Recueil Général 185 (3rd. ser.).

23 6 Hudson, International Legislation 83.

29 (1910) 17 C.C.C. 268 ; 15 West. L.R. 369.
} 
for themselves. Mathers C.J. of the Manitoba King's Bench, after citing Denman J.'s definition in Castioni, inquired:30

... was the crime of the accused committed in the furtherance of a political object? He belonged to the social democratic party, whose object was, not only to alter the form of government, but also to do away with private ownership of property. A propaganda was carried on by them throughout the country and numerous revolutionary outrages were perpetrated by them. ... [In view of the circumstances of the death,] can it be said that this killing was in furtherance of a political object? I think not. Nor do I think the fact the crime of the accused would, in the demanding State, be called a political crime and be tried by a special tribunal makes it a crime of a political character within the meaning of the [Anglo-Russian Treaty, $1886^{31}$ ]. The crime of killing a policeman by a person in no way identified with any political movement would in Russia be so described, and would be tried by the same tribunal.

This decision raises nice points in connection with the possible future claim for asylum as a political offender by a member of the Black Panters or the Weatherman fleeing from the United States and charged with the murder of a police officer.

Courts in the United States, ${ }^{32}$ France, ${ }^{33}$ and Chile ${ }^{34}$ have all upheld the view that the act must be directed against the political establishment of the country requesting the extradition, which would make it still more difficult for the individual hijacker to plead that he was nothing but a political offender. However, nowadays, a number of countries have come under dictatorial governments and no organised political activity other than that conducted by the governing party is tolerated. This has meant that in many cases individuals have fled from their country of residence because they were politically opposed to the system there prevailing, and feared discrimination or actual physical harm unless they left. Frequently, their flight has involved some criminal act, often involving the temporary or permanent seizure of some means of transportation. In March 1950 three Czech aircraft were diverted in flight to an airfield in the United States Zone of Occupation in Germany, and in two of the cases there was evidence that crew members had been threatened, manhandled and tied up, while the deviation of the third aircraft was carried out by crew members. Czechoslovakia requested the return of the hijackers, contending that they had committed crimes contrary to the Czech Penal Code, in that they had endangered the lives of passengers and crew, unjustifiably limited personal freedom, and kidnapped both passengers and crew, wrongfully taking them across the frontier. The United States pointed out that the treaties in force between herself and Czechoslovakia would not apply to effect the extradition of a person in the United States Zone of Occupation so that, since extradition was only possible because of a treaty, there was no basis for returning the alleged criminals. Moreover: ${ }^{35}$

\footnotetext{
wh Id at 270-271; at $370-371$ (in the decision of the Privy Council confirming this judgment, no reference is made to the nature of the offence as political or otherwise [1911] A.C. 735, for the reference was solely on procedure).

31 Acts of Canada, 1887, xcix - now tacitly regarded as inoperative by Britain, 478 Hansard (Commons), 1950 , col. 462.

32 See 4 Hackworth, Digest of International Law at 45 et seq.; 6 Whiteman, Digest of International Law at 799 et seq.; Hyde, International Law Chiefly as Interpreted and Applied by the United States at 1019 et seq. (2d. vol. 1947).

332 Kiss, Répertoire Francais de Droit International Public at 212 et seq.; see also Re Giovanni Gatti (1947) 14 Ann. Dig. at 145-146.

34 Re Campora (1957) 24 Int. Law Rep. 518 at 520.

3s Whiteman, supra, n. 32 at $810-811$.
} 
...it is clear that these individuals fled Czechoslovakia for political reasons by whatever means they could find to escape. It has never been the practice of the United States Government to take action which would have the effect of subjecting political offenders to criminal jurisdiction.... The United States Government [pursuing a principle which has been followed since $1853^{36}$ ], therefore sees no reason to assist in the enforcement of Czechoslovak internal law by returning the accused in this case. As a matter of comity, the United States authorities endeavoured, of course, to return to Czechoslovakia, as promptly as all necessary arrangements could be completed, persons from the planes who expressed a desire to return. The United States Government will continue strictly to observe such standards of international conduct. Comity, on the other hand, could not reasonably be construed to require the United States authorities to arrange for the return of those who were resolved to remain. In accordance with humanitarian principles, the latter have been given the right of political asylum.

A similar stance was adopted later in the year when the means of transportation was a hijacked train. ${ }^{37}$ Prima facie, such an attitude would render it difficult for the United States to request the return of a fugitive from, say, Algeria, Chile or Cuba, who maintained that he was diverting a United States aircraft to enable him to escape from the United States, the political system of which was such that he could no longer continue to live there and so sought "freedom". At the same time, it must be remembered that the United States now regards piracy of aircraft as a federal offence which, if violence has been used, makes the offender liable to the death penalty. The statute has no nationality limitation and would therefore extend even to an alien responsible for hijacking a foreign aircraft either inside or outside the United States, so long as it had its next scheduled destination or last point of departure in the United States and provided it next actually landed there. This may still leave the way open to grant political asylum to an alien causing a foreign aircraft to deviate from its flight plan and go to the United States instead.

These early hijackings were confined to offenders who possessed the same nationality as their means of transportation, and their acts only affected co-nationals. This does tend to lend some credence to the contention that, although there was no organised attempt to overthrow a government involved, the act was in fact political in character. This appears to be the view taken by the Swiss Federal Tribunal in 1952.38 Three crew members diverted a Yuoslav aircraft to Switzerland and the Yugoslav Government sought their extradition on the basis of the Swiss-Serbian Treaty, 1897, claiming that the fugitives had subjected the other crew members to unlawful restraint, endangered the safety of public transport and wrongfully appropriated property. The court was of opinion that: ${ }^{39}$

... all the offences with which the accused are charged were means to effectuate their escape abroad, and coincided completely with that escape. The question must therefore be examined whether that escape constituted a purely political offence; if so, extradition must be refused on the ground that the offences for which it is requested are not only connected with a purely political offence, but also constitute such an offence... . The purpose and motive of the acts with which the accused are charged was to enable them to flee from a country with whose régime they were not in agreement and where they felt themselves to be watched

\footnotetext{
${ }^{36}$ Koszta Incident, Sec. of State Marcy to Austrian Minister Hülsemann (September 26, 1853), In Wharton, International Law Digest at $483-486$ (2d vol. 1886).

37 Supra, n. 32 at 811.812.

30 In re Kavic, Bjelanovic and Arsenijevec, 19 Int. Law Reports 371.

3o Id. at 373-374.
} 
and repressed.... This fact gives both the flight and the offences committed to make it possible a distinctly political colouring. That is not, however, enough to exclude the possibility of extradition for these offences; it is also necessary that their political character should outweigh their common [law crime] characteristics.... The federal tribunal [has given] a restrictive interpretation to the concept of relative political offences, and required, in particular, that the act should be related to a general activity directly aimed at the realization of political aims and should have been committed in the framework of a fight for political power. This applies to the flight of a political opponent from the country if it is intended to continue the fight for power from abroad... . That restrictive interpretation does not, however,... take account of recent historical developments, such as the growth of totalitarian States. In such States all political opposition is suppressed and a fight for power is, if not impossible from the start, at least practically without any chance of success. Those who do not wish to submit to the regime have no alternative but to escape it by flight abroad... . This more passive attitude for the purpose of escaping political restraint is no less worthy of asylum than active participation in the fight for political power used to be in what were earlier considered to be normal circumstances. The spirit of justice undoubtedly ascribes a political character to such a flight abroad, and a liberalization of the practice of this Court, with a view to adjusting it to recent developments, appears justified. In matters of extradition in particular, the Court must not abandon that spirit in favour of legalistic considerations, and must take account of historical and political developments... . Recent practice has been too restrictive in making the relative political character of an offence dependent on its commission in the framework of a fight for power. Such a character must also be attributed to offences which were committed in order to escape the constraint of a State which makes all opposition and, therefore, the fight for power impossible. In this connection there can also be applied the principle that the relation between the purpose and the means adopted for its achievement must be such that the ideals connected with the purpose are sufficiently strong to excuse, if not justify, the injury to private property, and to make the offender appear worthy of asylum. Freedom from the constraint of a totalitarian State must be regarded as an ideal in this sense. In the present case the required relationship undoubtedly exists; for, on the one hand, the offences against the other members of the crew were not very serious, and, on the other, political freedom and even existence of the accused was at stake, and could only be achieved through the commission of these offences.

At one time it appeared as if the English courts, and presumably those that have tended to follow Castioni, were going to apply a somewhat similarly liberal approach to escapees. Ex parte Kolczyski ${ }^{40}$ concerned a request for extradition by the Polish Government of seven Polish trawlermen who had mutinied, seized the vessel after overpowering the captain and using violence against one crew member, and who had subsequently sought political asylum in England. By the Anglo-Polish Treaty of Extradition, 1932,41 kidnapping, false imprisonment, grievious bodily harm, revolt on the high seas against the authority of the master, and the like, were included in the list of extraditable offences, and it is difficult to see how any of these fall within the Castioni definition. Lord Goddard C.J., speaking for the Divisional Court, said, in words highly reminiscent of the Swiss Tribunal, that: 42

...the revolt of the crew was to prevent themselves being prosecuted for a political offence [-the political officer of the vessel, against whom the violence had been used, had been recording their 'treasonable' comments-] and... therefore the offence had a political character.

He pointed out that in the conditions that existed in Poland it was well nigh impossible for any offence to fall four-square within the classi-

\footnotetext{
to R. v. Governor of Brixton Prison, Ex parte Kolczynski and others [1955] 1 Q.B. 540.

135 B.F.S.P. 310.

12 Supra, n. 40 at 550 .
} 
cal definition, but he pointed out that the Castioni court had not purported to give an exhaustive definition and therefore the Court felt free to hold that: 43

...The evidence about the law prevalent in the Republic of Poland today shows that it is necessary, if only for reasons of humanity, to give a wider and more generous meaning to the words we are now construing, which we can do without in any way encouraging the idea that ordinary crimes which have no political significance will be thereby excused.

The United States Circuit Court of Appeals refused ${ }^{44}$ to follow Kolczynski and continued to apply the Castioni principle. In fact, in a later hearing concerning the same applicant, the United States Commissioner, sitting as an extradition magistrate, while upholding the plea that the offence involved was political in character, commented that:45

...generally speaking [a political offence] is an offense against the government itself or incident to political uprisings.... The crime must be incidental to and form a part of political disturbances. It must be in furtherance of one side or another of a bona fide struggle for political power.

Despite this apparently traditional approach to the problem, administrative officials in the United States have been enabled by such legislation as the Refugee Relief Act, 1953, to take a more liberal approach on occasion and this trend has sometimes found support from the courts. $^{46}$ A similar situation has developed in the Federal Republic of Germany, where the Federal Constitutional Court has come out in favour of the more liberal interpretation of political offences, so as to cover persons who, if extradited, "would be liable in their home country to suffer a measure of persecution involving danger to life and limb or restrictions of personal liberty for political reasons." 47

Despite these liberal trends, the English courts appear to have returned to the more traditional view of political offences and in Schtraks v. Government of Israel ${ }^{48}$ there was a reaffirmation of the authority of Castioni, although it was recognised by Viscount Radcliffe that: 49

...if...the idea of 'political offence' is not altogether remote from that of 'political asylum', it is easy to regard as a political offence, an offence committed by someone in furtherance of his design to escape from a political regime which he found intolerable. I have no criticism to make of the decision in ...Kolczynski, but the grounds on which it was decided are expressed too generally to offer much guidance for other cases in the future... The idea that lies behind the phrase 'offence of a political character' is that the fugitive is at odds with the State that applies for his extradition on some issue connected with the political control or government of the country.

In the light of the above attitudes to political offences it would not appear that aerial pirates would qualify for non-extradition, if the state claiming their return could base the request upon an extraditable offence. On the other hand, it must be conceded that when, as in

43 Id. at 551.

4 Karadzole v. Artukovic (1957) 247 F. 2d 198 at 203.

is U.S. v. Artukovic (1959) 170 F. Supp. 383 at 392.

46 See Dunat v. Hurney (1961) 297 F. 2d. 744 at 746, 753.

${ }^{47}$ Summarized, without name, in (1960) 54 Am. J. Int. L. 416 at 418.

"s [1964] A.C. 556.

c. Id. at 591. 
the Czech-United States instance, or for that matter in the Polish Seamen's Case (Kolczynski), the offence has been committed by nationals and directed against fellow nationals either directly as agents of the state, or incidentally to an offence directed against the state, and particularly when the offence is subordinate to an attempt to flee, then a case may be made, using the limiting language of the Swiss Federal Tribunal in the Yugoslav hijacking case, for recognising an aerial pirate who has not caused any real harm to any other passenger or crew member as a political offender entitled to asylum. But the most spectacular of the recent cases of piracy in the air have not been of this kind. These have involved hijackers possessing the nationality of one country who have directed their activities against another country, not always that of which the aircraft involved has been a "national", and frequently passengers of a third state have been endangered, the excuse of the hijacker being that he regards himself as a member of an organisation which is involved in hostilities, not necessarily amounting to war in the international sense of that term, ${ }^{50}$ directed against the country which is alleged to be the object of the hijacking. Perhaps the best example of this form of aerial piracy is to be found in the 1970 activities of Arab guerrillas who diverted-and in some cases destroyed-"neutral" aircraft so as to alert the world to their own cause, or to bring pressure upon the flag state of the aircraft in the hope that it might in turn put pressure on Israel, or to bring pressure against Israel since some of the passengers involved were Israelis or nonIsraeli Jews for whom Israel might feel some moral responsibility. This type of hijacking hardly fits into what has previously been regarded as the basis for affording an offender or a refugee political asylum. Even if one feels inclined to apply to such a hijacking the view of the Swiss Tribunal that the relationship between the means and the end must be considered in modern times before reaching a decision as to the political character of the act, it is difficult to extend such liberalism to hijackers of this kind. To hijack a civil aircraft with private passengers on board, some of whom might become "trigger-happy" in an attempt to foil the hijacking, involves so much danger to innocent lives that it far outweighs the desire to escape and is hardly incidental thereto. This is true whether the pirate is seeking to use the aircraft as a means of escape from an undesirable political climate, or-and perhaps even more so in this case-is seeking to effect some political action against the flag state or the state of which some of the passengers are nationals, or merely to make a political demonstration which will ensure him, or his cause, international publicity. It might even be possible to argue that, even if the aircraft against which action has been taken possesses the same nationality as the hijacker, or possesses the nationality of the country against which a political protest is being made, there is no possibility of regarding the act as political if passengers are on board, for the risk to which they are put, together with the risk facing other aircraft due to interference with normal flight plans, is so real and grave that it outweighs all other considerations.

It is clear that customary international law as well as the normal rules with regard to extradition do not adequately deal with the problem of aerial piracy. Even if, as appears to be likely in some 
cases, bilateral treaties are drawn up to cover this matter, the issue will still remain important and inadequately dealt with. The treaties in question will only apply to the countries which have entered into them, and it will be a small matter for a hijacker to choose as his place of destination a country which is not so bound. In any case, the problem has become so widespread and, with the increasing size of passenger aircraft, the number of countries likely to be involved in a single instance so large, that the only effective method of facing the problem is by way of multilateral treaty regulation. Perhaps the earliest significant contribution made on this level was the Tokyo Convention on Offences and Certain Other Acts Committed on Board Aircraft.51 The Convention is intended to apply to offences against penal law and to "acts which, whether or not they are offences, may or do jeopardize the safety of the aircraft or of persons or property therein or which jeopardize good order and discipline on board," when the aircraft is in flight, on the surface of the high seas or of any other area outside the territory of any State. But, while the Convention does not exclude any criminal jurisdiction under national law, it confirms that jurisdiction over offences and acts committed on board belongs to the state of registration. Nevertheless, it concedes to a state other than that of registration competence to interfere with an aircraft in flight in order to exercise criminal jurisdiction if:

...the offence has effect on the territory of such State; has been committed by or against a national or permanent resident of such State; is against the security of such State; consists of a breach of any rules or regulations relating to the flight or manoeuvre of aircraft in force in such State; or if the exercise of such jurisdiction is necessary to ensure the observance of any obligation of such State under a multilateral international agreement.

The Convention confirms the power of the aircraft commander to effect reasonable measures of restraint when he has reasonable grounds to believe that an offence of the kind forbidden is likely to be or has been committed on board his plane, and he has the right to call upon a contracting party in whose territory he has landed to take custody of the alleged offender in accordance with the local law, "for such time as is reasonably necessary to enable any criminal or extradition proceedings to the instituted." However, while in order to facilitate extradition proceedings, offences committed on aircraft belonging to contracting parties shall be treated as if they had been committed both in the place where they have occurred as well as in the state of registration, "nothing in this Convention shall be deemed to create an obligation to grant extradition". The Convention makes these powers of detention and arrest available to cover a person on board who:

...has unlawfully committed by force or threat thereof an act of interference, seizure, or other wrongful exercise of control of an aircraft in flight or when such an act is about to be committed, [and] Contracting States shall take all appropriate measures to restore control of the aircraft to its lawful commander or to preserve his control of the aircraft.... [Further,] the Contracting State in which the aircraft lands shall permit its passengers and crew to continue their journey as soon as practicable, and shall return the aircraft and its cargo to the persons lawfully entitled to possession.

The Convention does not oblige the State of landing to take criminal proceedings against the hijacker and, since it does not create any

31 1963, 704 UNTS No. 10106 ((1964) 2 Int. Legal Materials at 4042). 
obligation to extradite, the offender may merely suffer a temporary arrest and then be allowed to go free. This in fact seems to be the case, for it is expressly provided that:

...when such person cannot or does not desire to continue his journey and the State of landing refuses to admit him, that State may, if the person in question is not a national or permanent resident of that State, return him to the territory of the State of which he is a national or permanent resident or to the territory of the State in which he began his journey by air.

But there is no obligation to return him to the state of registration of the aircraft involved, nor does it appear as if the state of landing "may" return him to the flag state. The Convention makes no attempt to forbid the hijacker from raising the defence of political offence, presumably because the contracting parties remained determined to control their own extradition practices.

The Convention does not seem to have made a really appreciable impact on air piracy and at its Seventeenth (Extraordinary) Assembly in June 1970 the International Civil Aviation Organisation drew attention to the small number of states that had ratified the Tokyo Convention and called for its wider acceptance, so that it might become "a universally accepted international standard for the treatment to be accorded passengers and crews following the unlawful seizure of an aircraft." In order to fill some of the lacunae, the Organisation drew up a draft Convention on the unlawful seizure of aircraft, which was referred to a diplomatic conference at The Hague in December 1970. Although seventy-seven delegations attended, only fifty-one countries, including [Nationalist] China and the German Federal Republic, but excluding Cuba, the Democratic German Republic, the People's Republic of China and all the Arab countries had, by January 21, 1971, signed the Convention for the Suppression of Unlawful Seizure of Aircraft, ${ }^{52}$ but this Convention does not come into force until thirty days after it has been ratified by ten of the signatories. It is perhaps of interest to point out that:53

...the Canadian Delegation to The Hague Conference played an active role in promoting a generally acceptable treaty and was particularly instrumental in securing adoption of the strong prosecution provision.... The Canadian Government will now make a close study of the Convention with a view to ascertaining what national legislation will be required. When the required legislation has been enacted and other steps necessary to permit ratification have been taken, it is expected that Canada will become a party.

The Preamble to the Convention indicates that, broadly speaking, the parties cannot accept that hijackings can be excused as political actions, for it points out that such actions constitute a matter of grave concern and that in order to deter future offenders there is urgent need for appropriate measures of punishment to be provided. Moreover:

... unlawful acts of seizure or exercise of control of aircraft in flight jeopardize the safety of persons and property, seriously affect the operation of air services, and undermine the confidence of the peoples of the world in the safety of civil aviation.

Therefore, any person who "unlawfully, by force or threat thereof, or by any other form of intimidation" seizes or takes over control of an

s2 (1971) 10 Int. Legal Materials at 133.

s3 Canada, Dept. of External Affairs, Communique No. 86, December 16, 1970. 
aircraft in flight, or attempts so to do, or acts as an accomplice to anyone so doing commits an offence, and each contracting party undertakes to make such an offence punishable by severe penalty. An aircraft is considered to be in flight from the moment its doors are closed at embarkation until any door is opened for the purpose of disembarkation, and a forced landing is not deemed to be termination of the flight. The protection of the Convention is not extended to military, customs or police aircraft, and while it applies to both domestic and international flights, it does not apply to an aircraft if its place of take-off or actual landing is within the territory of the State of registration. This means that many of the acts of aerial piracy which have taken place of late would not be forbidden under the Convention. In the first place, it would not cover the sort of attack that was made on the ground in Switzerland, nor would it apply to a diversion of a service aircraft by a member of the services or by a civilian flying in such an aircraft or seizing it on the ground-but then military offences, generally speaking, are exempt from extradition processes, although the proposed British legislation extends to the seizure of all aircraft-nor will it apply to a deviation within the territory of the flag State as a result of which, for example, a Canadian plane scheduled to fly, let us say, from Toronto to Edmonton was forced to land instead at Winnipeg. However, provision is made to extend the operation of the Convention if the hijacker is found in a country other than that of registration. In order to ensure coordinated treatment of aerial pirates, the contracting parties are required to enact legislation whereby their courts will have jurisdiction over the hijacking or any act of violence directed against passengers or crew in connection therewith, when the offence is committed on an aircraft registered in that state, when the aircraft involved lands in its territory with the offender still on board, or when the aircraft has been leased without crew to a lessee who has his principal place of business, or failing that his permanent residence, in that state.

States are also required to amend their legislation to establish criminal jurisdiction over a hijacker present within their territory if the hijacker is not extradited, and the Convention seeks to amend all existing extradition treaties in force between contracting states so that an offence of this character shall be considered extraditable, and the contracting states undertake to include this offence in all future extradition treaties to which they become parties. Not only is this an example of a later multilateral treaty being used to amend a series of bilateral treaties among the parties to the multilateral treaty, but it is a case of a multilateral treaty supplementing treaties which are really only peripherally concerned with the subject matter of the later treaty. Moreover, the Convention provides that those countries which make extradition conditional upon the existence of a treaty may, at their option, treat the Convention as the basis for acting on a request from a country with which no other extradition treaty exists. On the other hand, it reserves all the local legal requirements in regard to extradition, and presumably therefore leaves open to the hijacker the plea that his offence was in fact political in character. This provision for extradition obviously imposes an obligation upon contracting parties which make the operation of an extradition treaty dependent on an authorising statute or on the principle of 
double criminality to amend their criminal and other legislation to give effect to this new international commitment. Moreover, if the state in which the offender is found does not extradite him, that state is obliged "without exception whatsoever and whether or not the offence was committed within its territory" to institute criminal proceedings in its own courts, "as in the case of any ordinary offence of a serious nature under the law of that State." Here we have an instance of the creation of an international crime subjected to universal jurisdiction, or more correctly to the jurisdiction of all those states which are parties to the Convention and, hopefully, that will mean all those involved in carriage by air, but differing from priacy and war crimes in that, by treating it as an ordinary serious offence under the local law, it does not apparently envisage application of the death penalty, even though some municipal authorities, for example the United States, have already made air piracy amenable to that punishment. The Convention also provides that the parties shall cooperate with each other in connection with criminal proceedings brought to deal with this offence. Finally, and this may well be an interesting breakthrough in view of the cosignature of the Soviet Union and the People's Republics, the parties undertake to settle any dispute concerning the application or interpretation of the Convention which has proved incapable of resolution by negotiation to arbitration, and if after six months it has proved impossible to agree on the organisation of such arbitration, either may refer the issue to the World Court by request. However, any party to the Convention is entitled to make a reservation excluding the operation of this settlement process, and while others will not be bound as regards a state making such a reservation, the latter may withdraw its reservation at any time, which may raise interesting problems concerning the temporal validity of the reservation and its withdrawal.

If the Convention of 1970 is brought into effect it may result in radically reducing the number of cases of aerial hijacking. But this will only occur if the contracting parties really make the penal clauses of the Convention effective, if they treat the offence as serious carrying a substantial penalty, if they exclude the defence of political offence even though this may be out of line with their traditional approach to extradition requests, and if they show a real intention of amending their criminal legislation in accordance with the requirements of the Convention. It is perhaps still too soon to expect many of the parties to have made the necessary examination of their criminal law and prepare the required amendments, but it is to be hoped that this action does not take as long as appears often to be necessary when major changes in the penal system are required. If the parties do in fact take the action required of them and make the Convention effective, it may serve as a most useful precedent for the creation of a proper international criminal law. In the meantime it is to be hoped that, pending the coming into force of this Convention, the states concerned will initiate and bring to an early successful conclusion bilateral negotiations in the same field, especially with countries which are not parties to the Convention as has been the case with Canada and Cuba. ${ }^{54}$

s4 Id. Communique No. 12, February 22, 1971. 